\title{
The proteasomes of two marine decapod crustaceans, European lobster (Homarus gammarus) and Edible crab (Cancer pagurus), are differently impaired by heavy metals
}

\author{
Sandra Götze ${ }^{\text {a }}$, Aneesh Bose ${ }^{\text {a }}$, Inna M. Sokolova ${ }^{\text {b }}$, Doris Abele ${ }^{\text {a }}$, Reinhard Saborowski ${ }^{\mathrm{a}, *}$ \\ a Alfred Wegener Institute, Helmholtz Centre for Polar and Marine Research, Functional Ecology, 27570 Bremerhaven, Germany \\ ${ }^{\mathrm{b}}$ Department of Biology, University of North Carolina at Charlotte, Charlotte, NC, USA
}

\section{A R T I C L E I N F O}

\section{Article history:}

Received 20 January 2014

Received in revised form 23 February 2014

Accepted 31 March 2014

Available online 8 April 2014

\section{Keywords:}

Proteasome

Lobster

Crab

Metal pollution

Cadmium

Mercury

Copper

Zinc

\begin{abstract}
A B S T R A C T
The intracellular ubiquitin-proteasome system is a key regulator of cellular processes involved in the controlled degradation of short-living or malfunctioning proteins. Certain diseases and cellular dysfunctions are known to arise from the disruption of proteasome pathways. Trace metals are recognized stressors of the proteasome system in vertebrates and plants, but their effects on the proteasome of invertebrates are not well understood. Since marine invertebrates, and particularly benthic crustaceans, can be exposed to high metal levels, we studied the effects of in vitro exposure to $\mathrm{Hg}^{2+}, \mathrm{Zn}^{2+}, \mathrm{Cu}^{2+}$, and $\mathrm{Cd}^{2+}$ on the activities of the proteasome from the claw muscles of lobsters (Homarus gammarus) and crabs (Cancer pagurus). The chymotrypsin like activity of the proteasome of these two species showed different sensitivity to metals. In lobsters the activity was significantly inhibited by all metals to a similar extent. In crabs the activities were severely suppressed only by $\mathrm{Hg}^{2+}$ and $\mathrm{Cu}^{2+}$ while $\mathrm{Zn}^{2+}$ had only a moderate effect and $\mathrm{Cd}^{2+}$ caused almost no inhibition of the crab proteasome. This indicates that the proteasomes of both species possess structural characteristics that determine different susceptibility to metals. Consequently, the proteasome-mediated protein degradation in crab C. pagurus may be less affected by metal pollution than that of the lobster H. gammarus.
\end{abstract}

(C) 2014 Elsevier Inc. All rights reserved.

\section{Introduction}

Industrial processes are major sources of anthropogenic metal pollution in the environment (Järup, 2003; Rainbow, 2007). Pollution often occurs locally, and variation among regions may depend on the composition and quantity of industrial discharges, as well as on the distance to the point source of pollution (Soto-Jiméneza and Páez-Osuna, 2001; Yuan et al., 2012; Gao et al., 2013). Trace metals such as cadmium $(\mathrm{Cd})$, mercury $(\mathrm{Hg})$, lead $(\mathrm{Pb})$, nickel $(\mathrm{Ni})$, or copper $(\mathrm{Cu})$ are common persistent pollutants in estuarine and coastal waters and sediments. Over the last several decades considerable increases in the concentrations of these metals have been reported in marine environments alongside severe impacts on ecosystems. For example, metal concentrations may reach $\sim 80 \mu \mathrm{g} \cdot \mathrm{L}^{-1}$ cadmium, more than $1 \mathrm{mg} \cdot \mathrm{L}^{-1}$ copper, or $500 \mathrm{ng} \cdot \mathrm{L}^{-1}$ mercury in marine surface waters depending on the site (US Department of Health and Human Services, Toxicological profiles, http://www.atsdr.cdc.gov/). These levels are often hundreds of times more concentrated than those from pristine control regions.

Metals are not naturally degradable in the marine environment and hence bio-accumulate and/or biomagnify along the food chains, often

\footnotetext{
* Corresponding author. Tel.: + 494714831 2220; fax: + 4947148311776.

E-mail address: Reinhard.Saborowski@awi.de (R. Saborowski).
}

with severe health consequences for higher trophic level organisms (Mance, 1987; Storelli and Marcotrigiano, 2003; Jung and Zauke, 2008; Bánfalvi, 2011; Ramakritinan et al., 2012). Toxic effects of metals mainly depend on the metal speciation and bioavailability, but also on the means of uptake, accumulation, and excretion rates of the organisms. The toxicity of borderline and class B metals (such as $\mathrm{Cu}, \mathrm{Zn}, \mathrm{Cd}$ and $\mathrm{Hg}$ ) is linked to their high affinity to sulfur- and nitrogen-rich compounds including cysteinyl and histidyl residues of proteins (Vallee and Ulmer, 1972; Eichhorn, 1976; Nieboer and Richardson, 1980). Hence, intracellular proteins are vulnerable to binding by metal ions, which may damage these proteins and impair their functions. However, essential trace metals such as $\mathrm{Cu}$ or $\mathrm{Zn}$ also act as important constituents of metalloenzymes (Lehninger, 1950) and only become toxic at high concentrations.

Cellular homeostasis requires the accurate regulation of cellular processes, and is crucial for cell proliferation, apoptosis, and even immune or stress responses. One key regulator of these processes is the ubiquitin-proteasome system (Fig. 1). This system is responsible for the precise degradation of more than $80 \%$ of short-living or malfunctioning proteins (Baumeister et al., 1998; Voges et al., 1999; Ciechanover, 2005). A disruption of this system has been linked with severe cellular dysfunctions and diseases (Ciechanover and Brundin, 2003; Powell et al., 2005). Class B metals are known stressors of the 


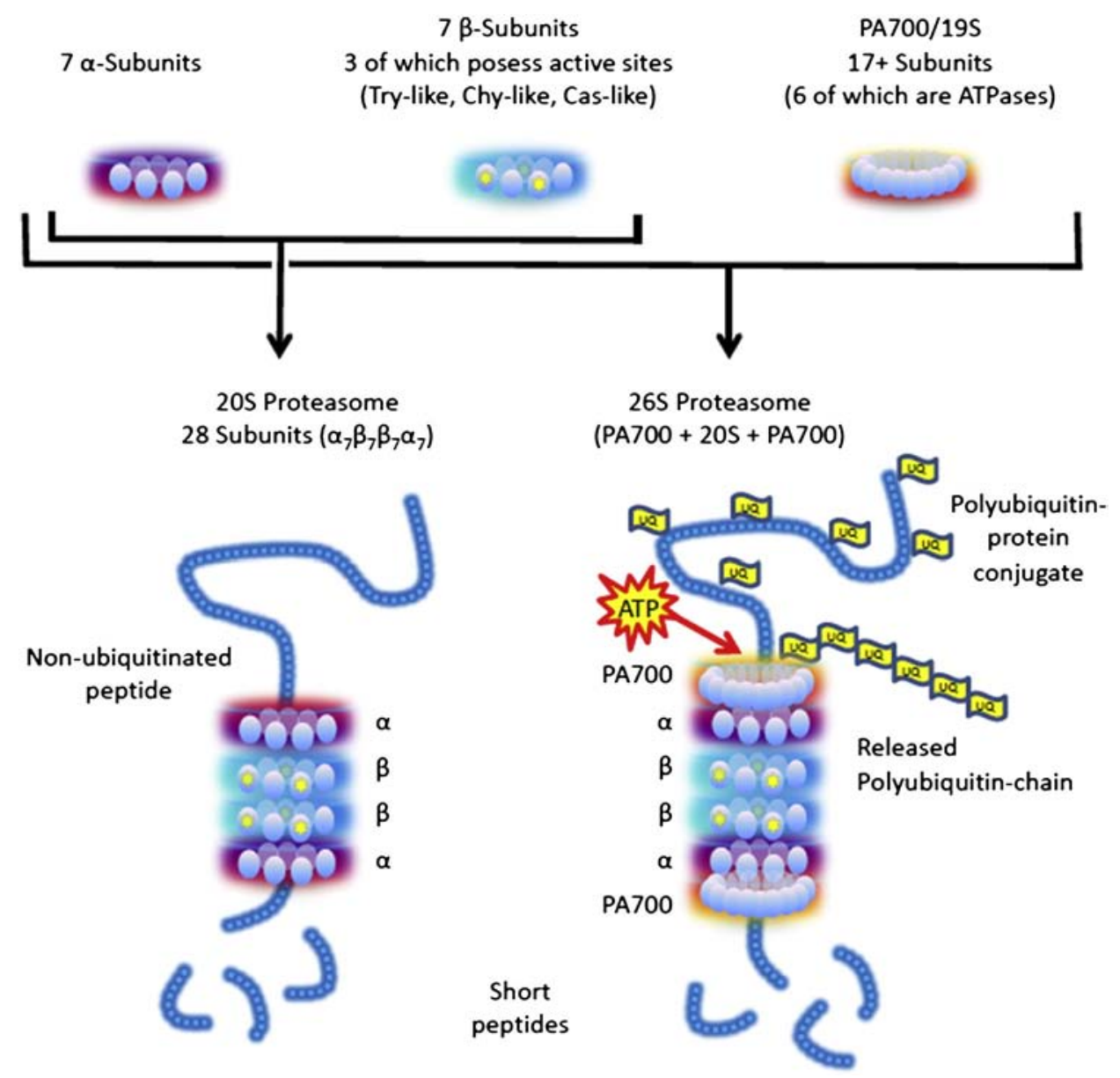

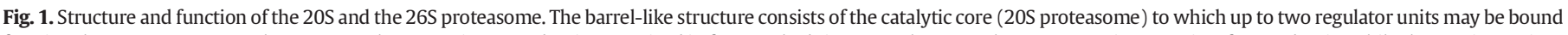

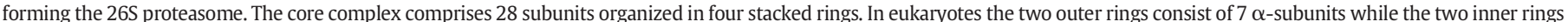

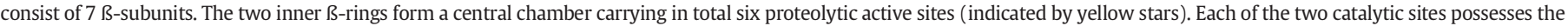

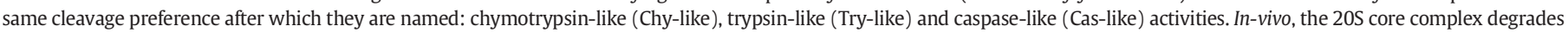
mainly oxidatively damaged proteins in an ubiquitin-independent manner while the $26 \mathrm{~S}$ proteasome degrades only short-living ubiquitinated proteins.

proteasome system. Metal ions can impair proteasome function directly or indirectly by respectively binding to the proteasome complex or by the generation of oxidative stress (Figueiredo-Pereira and Cohen, 1999; Grune, 2000; Pena et al., 2008).

Marine invertebrates, such as bivalves and crustaceans, are of high ecological and economic importance (e.g. Costello et al., 2010; Boudreou and Worm, 2012; FAO, 2012). Many of these species serve as sentinel organisms for monitoring environmental pollution in estuaries and coastal areas (Najle et al., 2000; Mirza et al., 2012). However, studies investigating the effects of class B metals on proteasome activities in marine crustacean species are sparse. To address this gap in our knowledge, we studied the in-vitro effects of $\mathrm{Cu}^{2+}, \mathrm{Zn}^{2+}, \mathrm{Hg}^{2+}$ and $\mathrm{Cd}^{2+}$ on the proteasome activity in two common decapods species, European lobster (Homarus gammarus) and edible crab (Cancer pagurus). The results demonstrate species-specific sensitivity of the proteasome of lobsters and crabs to metals, and provide a basis for future contributions to our understanding of sub-cellular effects of metals and their toxicity in marine decapods.

\section{Materials and methods}

\subsection{Animal collections}

European lobsters (H. gammarus) were purchased from a seafood merchant (CuxFisch Ditzer GmbH, Cuxhaven, Germany). The animals were captured off the Danish North Sea coast. Body lengths and masses of the animals were 15 to $20 \mathrm{~cm}$ and 500 to $550 \mathrm{~g}$, respectively. Edible crabs (C. pagurus) were collected from bottom trawls with R/V Uthörn off the island of Helgoland (German Bight, North Sea). Carapace widths and body masses ranged from 10 to $15 \mathrm{~cm}$ and 250 to $450 \mathrm{~g}$, respectively.

\subsection{Preparation of extracts}

Muscle tissues were dissected from the chelae of adult H. gammarus and $C$. pagurus, shock frozen in liquid nitrogen, ground to a fine powder by mortar and pestle, and stored at $-80{ }^{\circ} \mathrm{C}$ until further analysis. About $1.2 \mathrm{~g}$ of the powdered tissue samples were resuspended in $4 \mathrm{~mL}$ of assay buffer (0.05 M Tris-(hydroxymethyl) aminomethane, $0.025 \mathrm{M} \mathrm{KCl}, 0.01$ $\mathrm{M} \mathrm{NaCl}, 0.001 \mathrm{M} \mathrm{MgCl}_{2}$, $\mathrm{pH} 8.0$ ). The suspensions were homogenized on ice with an ultrasonic cell disruptor (Branson, Sonfier B15) and centrifuged for $35 \mathrm{~min}$ at $13,000 \mathrm{~g}\left(4^{\circ} \mathrm{C}\right)$. The supernatants were used directly for ultracentrifugation on a glycerol density gradient.

\subsection{Glycerol density ultra-centrifugation}

The proteasome fraction was partly cleaned up by glycerol density ultracentrifugation. Linear glycerol gradients of $20 \mathrm{~mL}$ glycerol (ranging from $10 \%$ to $40 \%$ ) were prepared in assay buffer ( $50 \mathrm{mM}$ Tris, $40 \mathrm{mM}$ $\mathrm{KCl}, 5 \mathrm{mM} \mathrm{MgCl}$, $2 \mathrm{mM} \mathrm{ATP}$ ) with a gradient maker (Pharmacia Biotec, 80-1315-58) using polycarbonate tubes (Beckman Coulter, 355618). Crude muscle extracts $(4 \mathrm{~mL})$ were applied onto the gradients and 
centrifuged for $15 \mathrm{~h}$ at $67,000 \mathrm{~g}$ at $4{ }^{\circ} \mathrm{C}$ with an ultracentrifuge (Beckman Coulter L7-80) equipped with a 70 Ti fixed-angle rotor. Fractions of $2 \mathrm{~mL}$ each were taken along the density gradient from the top to the bottom of the tubes and transferred into reaction tubes. The pellets were resuspended in $300 \mu \mathrm{L}$ assay buffer and also transferred into reaction tubes. All fractions were placed on ice.

\subsection{Measurements of proteasome activities}

The chymotrypsin-like, trypsin-like, and caspase-like activities of the $20 \mathrm{~S} / 26 \mathrm{~S}$ proteasome were determined with the fluorogenic substrates Suc-Leu-Leu-Val-Tyr-AMC (Bachem, I-1395), Boc-Leu-ArgArg-AMC (Bachem, I-1585), and Gly-Pro-Leu-Asp-AMC (Enzo Life Science, BML-AW9560), respectively. Verification that solely proteasome activity contributed to the measured proteolytic activity was achieved by running parallel assays containing the highly specific proteasome inhibitor epoxomicin (PeptaNova, 4381) (Meng et al., 1999; Götze et al., 2013). All assays were performed in 96-well plates in a total volume of $50 \mu \mathrm{L}$ per assay, containing $40 \mu \mathrm{L}$ of assay buffer $(0.05 \mathrm{M}$ Tris(hydroxymethyl)-aminomethane, $25 \mathrm{mM} \mathrm{KCl}, 10 \mathrm{mM} \mathrm{NaCl}, 1 \mathrm{mM}$ $\mathrm{MgCl}_{2}$, and $2 \mathrm{mM}$ adenosine triphosphate (ATP), $\mathrm{pH} 8.0$ at $30{ }^{\circ} \mathrm{C}$ ) and $5 \mu \mathrm{L}$ of sample extract. Reactions measuring total proteolytic activity also contained $2.5 \mu \mathrm{L}$ of dimethylsulfoxide (DMSO), while the reactions measuring the proteasome-inhibited proteolytic activity contained $2.5 \mu \mathrm{L}$ of $1 \mathrm{mM}$ epoxomicin dissolved in DMSO (final concentration in the assay $50 \mu \mathrm{M}$ ). The reactions were initiated by the addition of $2.5 \mu \mathrm{L}$ of substrate ( $10 \mathrm{mM}$; final concentration in the assay $0.5 \mathrm{mM}$ ). The initial fluorescence values were immediately read in a microplate fluorometer at $355 \mathrm{~nm}$ excitation and $460 \mathrm{~nm}$ emission (Fluoroscan Ascent, Thermo Scientific). The reaction was allowed to proceed for $1 \mathrm{~h}$ in the dark at $30{ }^{\circ} \mathrm{C}$ in a microplate incubator (CAT, SH26) before the plate was read again. The difference in the relative fluorescence units (RFU) between the final and the initial reads served as a measure of the enzyme activity. The amount of the released product, 7-amino-4-methylcoumarin (AMC), was calculated on the basis of a standard curve, and expressed as $\mathrm{U} \cdot \mathrm{g}^{-1}$ protein $\left(\mathrm{U}=\mu \mathrm{mol} \mathrm{AMC} \cdot \mathrm{min}^{-1}\right)$. The protein content was determined after Bradford (1976) with a commercial dye reagent (BioRad, 500-0006) and bovine serum albumin as standard.

To test the sensitivity of the proteasome to trace metals $\left(\mathrm{Hg}^{2+}, \mathrm{Zn}^{2+}\right.$, $\mathrm{Cu}^{2+}$, and $\left.\mathrm{Cd}^{2+}\right)$, the chymotrypsin-like proteasome activities were measured as described above in the proteasome-enriched pellet fraction obtained by the gradient ultracentrifugation. The assays were conducted in the metal-free assay buffer or in the buffer supplemented with 10 to $100 \mu \mathrm{M}$ of $\mathrm{Cu}^{2+}, \mathrm{Zn}^{2+}, \mathrm{Hg}^{2+}$ and $\mathrm{Cd}^{2+}$ (added as the respective chloride salts). The chymotrypsin-like proteasome activities in the presence of metals were calculated relative to the corresponding control assays (without metal additions) and expressed as mean activity (\%) \pm the standard error of the mean (SEM) of three replicates $(n=3)$.

\subsection{Statistics and graphs}

The percent data were arcsin square root transformed and analyzed with a one-way ANOVA and Tukey post-hoc test. Significant differences between species, and/or the metals are indicated in graphs by different letters when $p$ values were below 0.05 . For each metal and species the half maximal inhibitory concentration $\left(\mathrm{IC}_{50}\right.$ ) was calculated by applying the sigmoidal function:

$y=\frac{\min +(\max -\min )}{1+\left(\frac{x}{E C_{50}}\right)^{\text {Hillslope }}}$.

Calculations and graph were done with the computer program SigmaPlot/Sigma Stat. 12.0.

\section{Results}

\subsection{Proteasome activities in lobsters and crabs}

The proteasome (20S/26S) of both species was effectively purified by glycerol-density ultracentrifugation. Proteasome activity was present in the last quarter of the gradient with increasing activities towards the pellet (Fig. 2). The highest activities towards all three substrates (representing the chymotrypsin-, trypsin-, and caspase-like activity) were found in the pellets, in accordance with the calculated sedimentation coefficient of the 20S/26S proteasome at the applied conditions. Furthermore, all three activities were completely (100\%) inhibited by epoxomicin proving that solely proteasome activity was measured.

$H$. gammarus had higher average activities of all catalytic sites of the proteasome than C. pagurus (Fig. 3). However, a significant difference between the two species was only found for the trypsinlike activity $(\mathrm{p}=0.002)$. For both crustaceans trypsin-like activities (TRY) were the highest, followed by chymotrypsin-like (CHY) activities and last by caspase-like (CAS) activities. In H. gammarus the trypsin-like activity amounted to $0.0058 \pm 0.0022 \mathrm{U} \cdot \mathrm{g}^{-1}$ prt, the chymotrypsin-like activity to $0.0250 \pm 0.0011 \mathrm{U} \cdot \mathrm{g}^{-1}{ }_{\mathrm{prt}}$, and the caspase-like activity to $0.0010 \pm 0.0006 \mathrm{U} \cdot \mathrm{g}^{-1}$ prt (all mean $\pm \mathrm{SEM}$; Fig. 3a). The trypsin-like activity was significantly higher than the two other activities (TRY to CHY: $\mathrm{p}=0.04$ and TRY to CAS: $\mathrm{p}=0.004$ ). The chymotrypsin-like activity and the caspase-like activity did not differ from each other. In C. pagurus the trypsin-like activity amounted to $0.0009 \pm 0.0003 \mathrm{U} \cdot \mathrm{g}^{-1}$ prt , the chymotrypsin-like activity amounted to $0.0006 \pm 0.0002 \mathrm{U} \cdot \mathrm{g}^{-1}$ prt , and the caspase-like activity amounted to $0.0002 \pm 0.0001 \mathrm{U} \cdot \mathrm{g}^{-1}$ prt (Fig. 3b). In the crab, activities were not significantly different from each other.

\subsection{Effects of metals}

The effect of metal ions was determined for the chymotrypsin-like activity of the proteasome since this catalytic site has a prominent role for the overall protein breakdown (Rock et al., 1994; Heinemeyer et al., 1997). Accordingly, inhibition of this site will affect cells (organisms) more severely than inhibition of the two other catalytic sites. Our study revealed that metal ions inhibited this catalytic site in a species- and concentration-dependent manner (Fig. 4). The lobster proteasome was more sensitive towards all investigated metals than the crab proteasome. In H. gammarus, the activity was strongest inhibited by mercury $\left(\mathrm{Hg}^{2+}\right)$ with a complete inhibition at $100 \mu \mathrm{M} \mathrm{Hg}^{2+}$. The other three tested metal ions, $\mathrm{Cu}^{2+}, \mathrm{Zn}^{2+}$, and $\mathrm{Cd}^{2+}$ caused 76.0$78.6 \%$ inhibition of the chymotrypsin-like proteasomal activity at $100 \mu \mathrm{M}$ (Figs. 4, 5). The degrees of inhibition by $\mathrm{Cu}^{2+}, \mathrm{Zn}^{2+}$, and $\mathrm{Cd}^{2+}$ were not significantly different from each other, while inhibition by $\mathrm{Hg}^{2+}$ was significantly stronger than by any of the other three metals $(\mathrm{p}<0.04)$.

Similar to the lobster, the proteasome of $C$. pagurus was the strongest inhibited by $\mathrm{Hg}^{2+}(100 \%$ inhibition at $100 \mu \mathrm{M})$. The second most potent inhibitor was copper with a $66.3 \% \pm 3.5 \%$ reduction of the chymotrypsin-like proteasomal activity at $100 \mu \mathrm{M}$. Zinc had only a weak effect on the proteasome activity with $39.1 \% \pm 8.5 \%$ at $100 \mu \mathrm{M}$. Cadmium had no significant effect on the chymotrypsin-like activity of the crab proteasome (Figs. 4,5 ).

\subsubsection{Effect of $\mathrm{Hg}^{2+}$}

Mercury caused the strongest inhibition of the chymotrypsin-like proteasome activity in both species (Fig. $4 \mathrm{a}$ and b). In the lobsters, $10 \mu \mathrm{M} \mathrm{Hg}^{2+}$ significantly decreased the activity to $43 \%$ residual activity (Fig. 4a; $\mathrm{p}=0.03$ ). At $25 \mu \mathrm{M} \mathrm{Hg}^{2+}$ only $8.2 \% \pm 5.8 \%$ of the initial activity remained. Concentrations of more than $25 \mu \mathrm{M}$ completely inhibited all activity ( $\mathrm{p}=0.001$ ). The chymotrypsin-like activity of $C$. pagurus was not significantly inhibited below $25 \mu \mathrm{M} \mathrm{Hg}^{2+}$ (Fig. 4b). At $25 \mu \mathrm{M}$ the activity decreased to $16 \% \pm 16 \%$ of the initial activity ( $p<0.001$ ). At more 

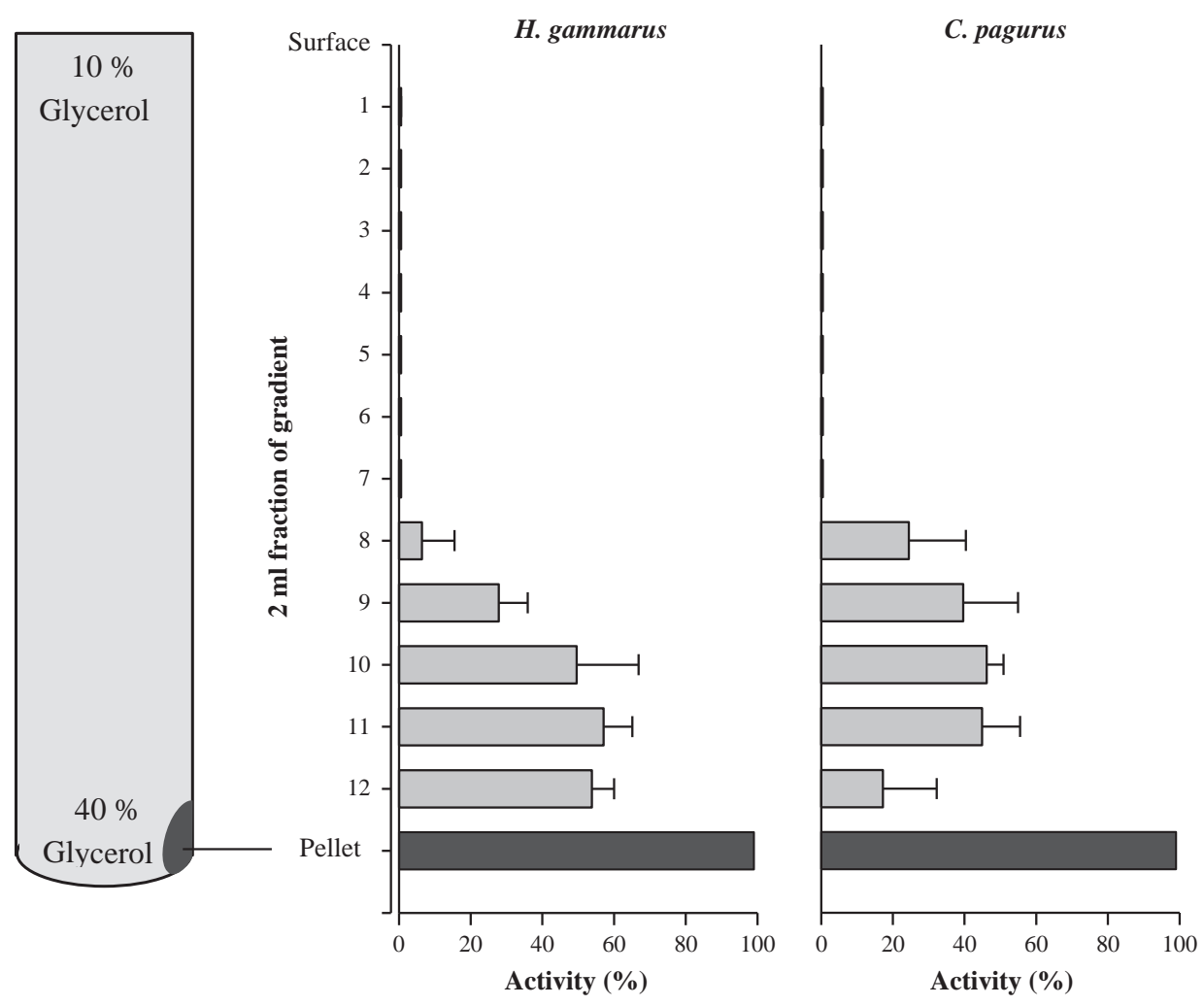

Fig. 2. Proteasome activity along the glycerol-density gradient after ultracentrifugation of extracts from the lobster H. gammarus and the crab C. pagurus. Means + SEM, $\mathrm{n}=3$.

than $25 \mu \mathrm{M} \mathrm{Hg}^{2+}$ no activity remained. The half maximal inhibitory concentration $\left(\mathrm{IC}_{50}\right)$ of mercury on the chymotrypsin-like activity was reached at $10.8 \mu \mathrm{M} \pm 0.7 \mu \mathrm{M}$ in the lobster and at $13.4 \mu \mathrm{M} \pm 3.4 \mu \mathrm{M}$ $\mathrm{Hg}^{2+}$ in the crab.

\subsubsection{Effect of $\mathrm{Zn}^{2+}$}

Zinc ions affected the chymotrypsin-like activity of either species in a different way (Fig. 4c and d). In lobsters, the activity decreased significantly to $57.7 \pm 11.3 \%$ in the presence of $10 \mu \mathrm{M} \mathrm{Zn}{ }^{2+}$ (Fig. $4 c ; p=0.002$ ), and only $21.4 \% \pm 11.7 \%$ of the residual activity remained in the $100 \mu \mathrm{M} \mathrm{Zn}{ }^{2+}$ treatment. The proteolytic activity at

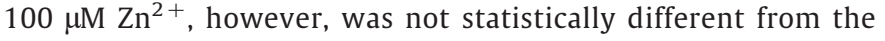

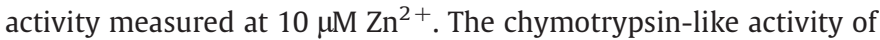
C. pagurus was less affected by $\mathrm{Zn}^{2+}$ than the activity of $H$. gammarus (Fig. 4d). The activity remained unaffected up to a concentration of $25 \mu \mathrm{M} \mathrm{Zn}{ }^{2+}$. There was a slight reduction in activity at $50 \mu \mathrm{M} \mathrm{Zn}{ }^{2+}$, and a significant decrease at $100 \mu \mathrm{M} \mathrm{Zn}^{2+}(69.3 \% \pm 8.5 \%$; $=0.003)$. In $H$. gammarus, the $\mathrm{IC}_{50}$ of zinc was reached at $11.3 \mu \mathrm{M} \pm 9.0 \mu \mathrm{M}$ $\mathrm{Zn}^{2+}$, and in C. pagurus at $56.1 \mu \mathrm{M} \pm 19.4 \mu \mathrm{M} \mathrm{Zn^{2+ }}$.

\subsubsection{Effect of $\mathrm{Cu}^{2+}$}

The chymotrypsin-like activity of H. gammarus decreased significantly to $66.2 \% \pm 9.6 \%$ in the presence of $10 \mu \mathrm{M} \mathrm{Cu}^{2+}$ (Fig. $4 \mathrm{e} ; \mathrm{p}=0.02$ ). Higher $\mathrm{Cu}^{2+}$ concentrations caused a stronger, although not significant,
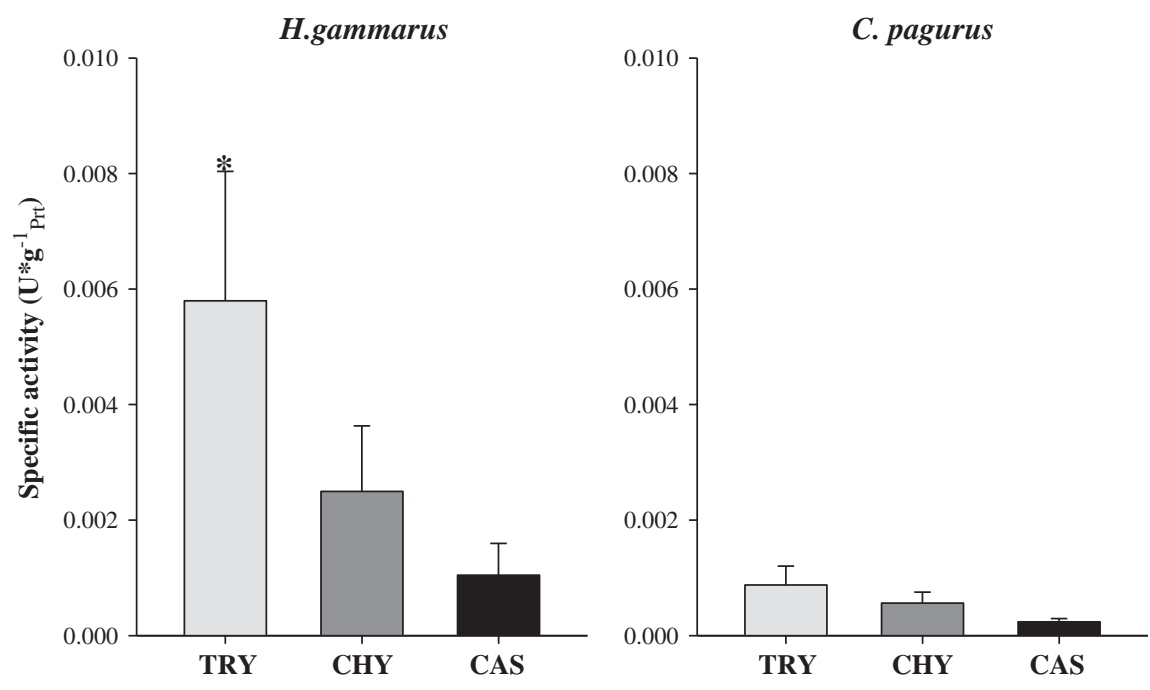

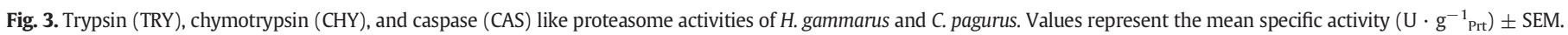
Significant differences between species are indicated by the asterisks when $\mathrm{p}<0.05(\mathrm{n}=3)$. 


\section{H. gammarus}
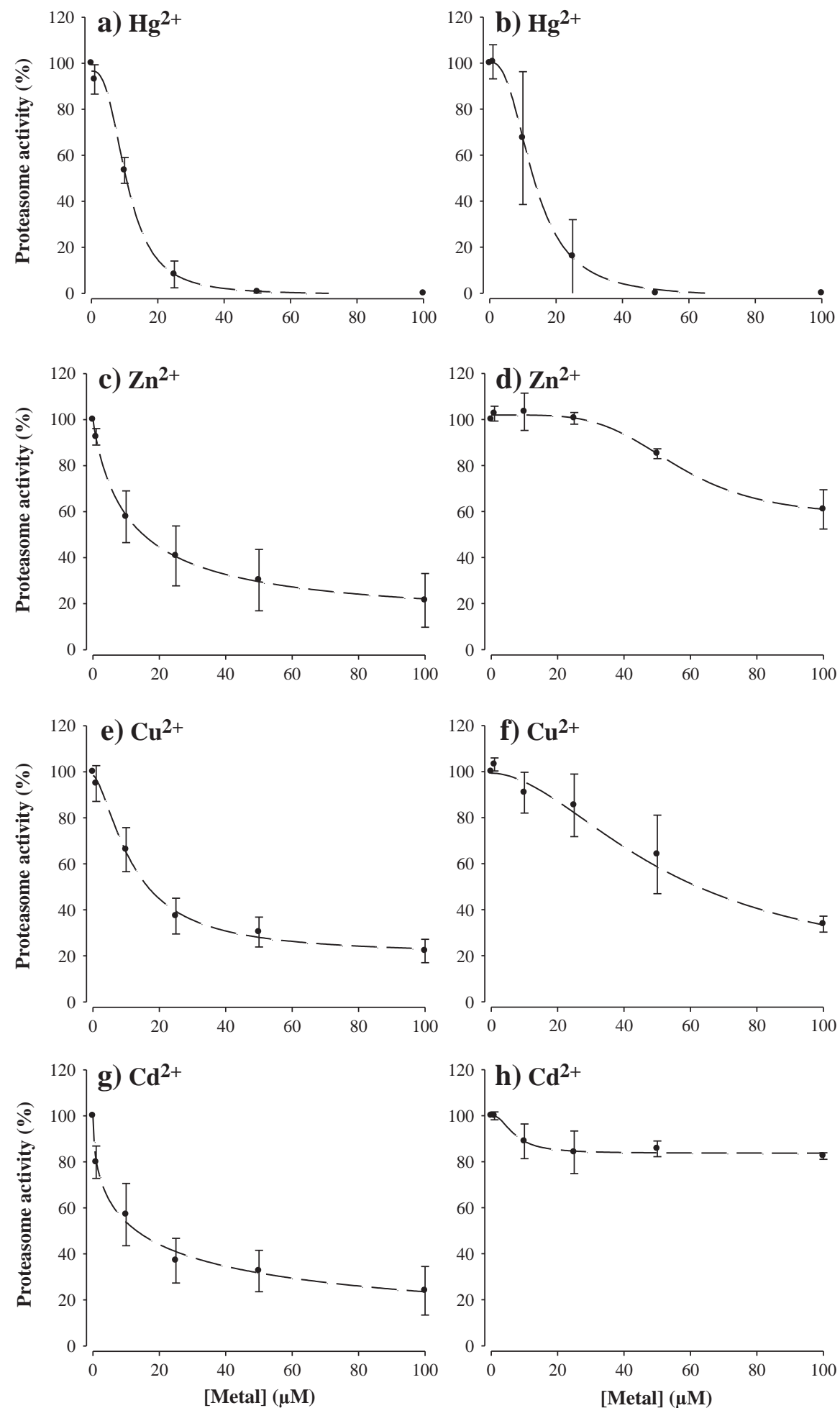

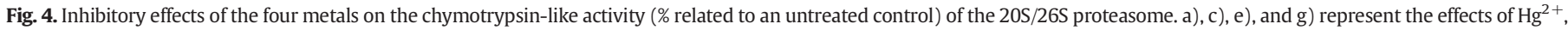
$\mathrm{Zn}^{2+}, \mathrm{Cu}^{2+}$, and $\mathrm{Cd}^{2+}$ on the proteasome of H. gammarus. b) d), f), and h) represent the effects of $\mathrm{Hg}^{2+}, \mathrm{Zn}^{2+}, \mathrm{Cu}^{2+}$, and $\mathrm{Cd}^{2+}$ on the proteasome of $C$. pagurus.

decrease of activity. At $100 \mu \mathrm{M} \mathrm{Cu}{ }^{2+}$ only $22.1 \pm 5.09 \%$ of the initial activity was left. In contrast, the chymotrypsin-like activity of $C$. pagurus decreased slowly but not significantly up to $25 \mu \mathrm{M} \mathrm{Cu}{ }^{2}$ (Fig. 4f). At $25 \mu \mathrm{M}$ $\mathrm{Cu}^{2}$ the activity decreased significantly to $64.1 \% \pm 17.1 \%(\mathrm{p}=0.02)$. The $\mathrm{IC}_{50}$ in H. gammarus was reached at $12.3 \mu \mathrm{M} \pm 3.2 \mu \mathrm{M} \mathrm{Cd}^{2+}$ and in C. pagurus at $40.0 \mu \mathrm{M} \pm 11.1 \mu \mathrm{M} \mathrm{Cd}^{2+}$.

\subsubsection{Effect of $\mathrm{Cd}^{2+}$}

Cadmium had different effects on the chymotrypsin-like activity of the lobster and crab. (Fig. $4 \mathrm{~g}$ and $\mathrm{h}$ ). In lobsters the activity decreased significantly in the presence of $10 \mu \mathrm{M} \mathrm{Cd}^{2+}$ to $57 \% \pm 13.6 \%(\mathrm{p}=0.001)$. Higher concentrations up to $100 \mu \mathrm{M} \mathrm{Cd}^{2+}$ continuously reduced the activity down to $22 \% \pm 13.6 \%$ at $100 \mu \mathrm{M} \mathrm{Cd}^{2+}$. The chymotrypsin-like 


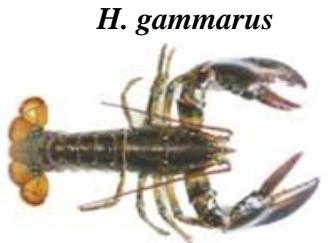

\section{$\mathrm{Hg}^{2+}$}

Max. IS: $100 \%^{\mathbf{a}}$

$\mathrm{IC}_{50}: 10.8 \pm 0.7 \mu \mathrm{M}$

\section{C. pagurus}

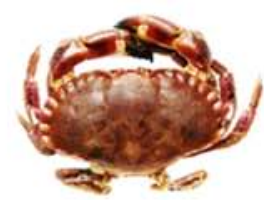

$$
\mathrm{Hg}^{2+}
$$

Max. IS: $100 \%^{\text {a }}$

$\mathrm{IC}_{50}: 13.4 \pm 3.4 \mu \mathrm{M}$

\section{$\mathrm{Zn}^{2+}$}

Max. IS: $78.6 \pm 11.7 \%^{\text {b }}$

$\mathrm{IC}_{50}: 11.3 \pm 9.0 \mu \mathrm{M}$

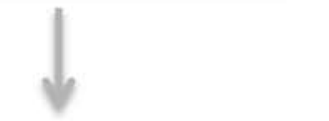

\section{$\mathrm{Cu}^{2+}$}

Max. IS: $77.8 \pm 5.1 \%^{\mathbf{b}}$

$\mathrm{IC}_{50}: 12.3 \pm 3.2 \mu \mathrm{M}$
Max. IS: $66.3 \pm 3.5 \%^{\mathbf{b}}$

IC $_{50}: 40.0 \pm 11.1 \mu \mathrm{M}$
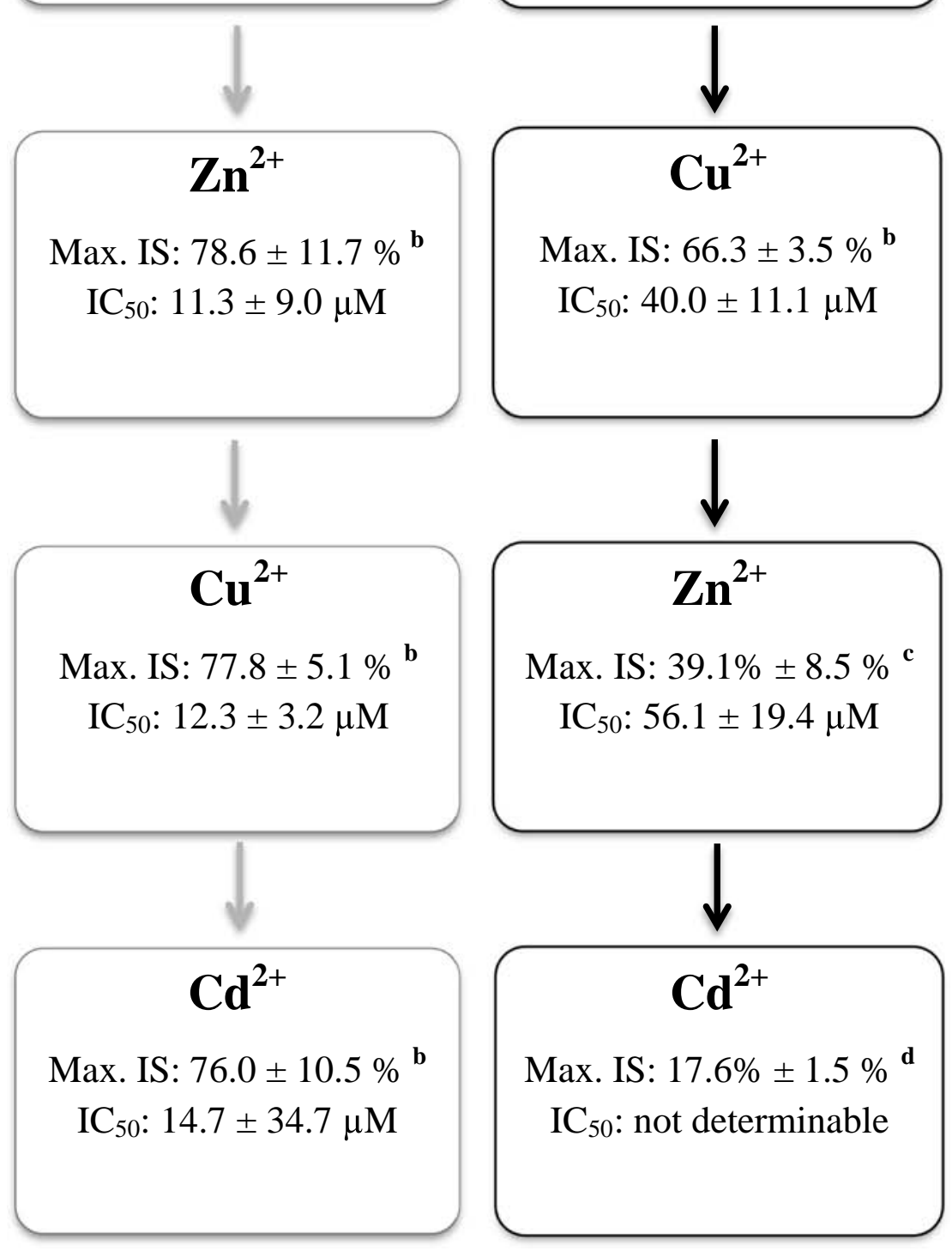

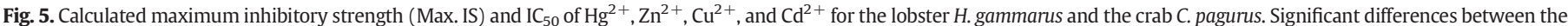
max. IS of metals within the same species are indicated by the different letters when $\mathrm{p}<0.05(\mathrm{n}=3)$.

activity of $C$. pagurus was not significantly inhibited by any of the applied $\mathrm{Cd}^{2+}$ concentrations $(\mathrm{p}>0.05)$. At $100 \mu \mathrm{M} \mathrm{Cd}^{2+} 82.5 \% \pm 1.44 \%$ of the initial activity remained. The $\mathrm{IC}_{50}$ for cadmium of $H$. gammarus was reached at $14.7 \mu \mathrm{M} \pm 34.7 \mu \mathrm{M} \mathrm{Cd}^{2+}$.

\section{Discussion}

The proper operation of the proteasome and associated pathways is crucial for cellular function and stress resistance. Intracellular excess of 
borderline and class B metals has been shown to damage and modulate these pathways in vivo with severe negative effects for organisms (Amici et al., 2002; Kim et al., 2004; Pena et al., 2008; Yu et al., 2010; Kanthasamy et al., 2012). Here we show for the first time that the invitro functionality of crustacean proteasomes is impaired by metal ions. The fraction that we separated by glycerol-gradient centrifugation contained most likely both, the 20S and the 26S population of the proteasome. Previous studies on crustaceans showed that both forms of the proteasome are active under physiological conditions (Mykles, 1998, 1999a,b; Götze and Saborowski, 2011). Therefore, the use of a mixed population of the proteasome appears suitable for our study. The observed effects on the proteasomes were surprisingly different between species, despite the fact that both crustaceans originate from unpolluted benthic habitats of the North Sea and share similar life styles and feeding modes. The proteasome of the crab C. pagurus displayed wide variation in responses to different metal ions. It was severely inhibited by $\mathrm{Hg}$, while being less sensitive to $\mathrm{Cu}$ and $\mathrm{Zn}$, and almost unaffected by $\mathrm{Cd}$. In contrast, all metals ( $\mathrm{Hg}, \mathrm{Zn}, \mathrm{Cu}$, and $\mathrm{Cd}$ ) inhibited the proteasome of the lobster, $H$. gammarus, to similar degrees.

Metal ions can bind to proteins of the regulatory complexes, as well as to the core proteins of the proteasome complex (Fig. 1). In the core proteins, especially the terminal threonine amino acids in the ß-sites, and the $\mathrm{Mg}^{2+}$-containing catalytic centers, were identified to have high affinities for various metal ions (Jover et al., 2008). Both essential metals, $\mathrm{Cu}$ and $\mathrm{Zn}$, showed different and species-specific inhibitory effects on the crustacean proteasomes. Copper is one of the most effective metal proteasome inhibitors known for vertebrate species (Kim et al., 2004; Milacic et al., 2008; Pena et al., 2008). This metal attacks the 20S core complex at the chymotrypsin-like catalytic site (ß5) and affects both the 20S and the 26S proteasome populations (Daniel et al., 2004). Zinc interferes mainly with the JAMM domain of the 19S regulatory complex, and inhibits predominantly the $26 \mathrm{~S}$ proteasome (Cvek et al., 2008). One possible explanation for the observed differences in the crustacean proteasome sensitivity towards metals may be due to adaptive or regulatory mechanisms. Especially the concentrations of essential metals can be regulated within appropriate intracellular levels, for example during elevated metal exposure (Stoeppler and Nürnberg, 1979; Rainbow and White, 1989). This regulatory capacity is often species-specific and depends on physiological traits such as osmoregulatory capacity, excretion rates, the ability to eliminate metals through ecdysis, and induction of detoxification pathways (Engel, 1987; Viarengo and Nott, 1993; Engel et al., 2001; Ahearn et al., 2004; Rainbow, 2007). For example, the rockpool prawn, Palaemon elegans, is capable of maintaining its internal concentrations of $\sim 76 \mu \mathrm{g} \mathrm{Zn} \mathrm{g}{ }^{-1}$ dry mass and $\sim 125 \mu \mathrm{g} \mathrm{Cu} \mathrm{g}^{-1}$ dry mass when exposed to up to $315 \mu \mathrm{g} \cdot \mathrm{L}^{-1} \mathrm{Zn}$ and $100 \mu \mathrm{g} \cdot \mathrm{L}^{-1} \mathrm{Cu}$ in seawater before a net accumulation starts (Rainbow and White, 1989).

H. gammarus has a natural concentration of $\sim 10 \mu \mathrm{g} \mathrm{Cu}$ and $26 \mu \mathrm{g} \mathrm{Zn}$ per gram wet mass of the muscle tissue (Barrento et al., 2008). C. pagurus has similar $\mathrm{Cu}$ concentrations in its muscle tissue $(\sim 8 \mu \mathrm{g} \mathrm{Cu}$ $\mathrm{g}^{-1}$ wet mass), but more than double the concentration of $\mathrm{Zn}(\sim 60 \mu \mathrm{g}$ $\mathrm{g}^{-1}$ wet mass) (Berge and Brevik, 1996). These $\mathrm{Zn}$ concentrations correspond to $\sim 0.5 \mathrm{mM}$ in lobster and $\sim 1.2 \mathrm{mM} \mathrm{Zn}$ in crab and are much higher than the in-vitro concentrations investigated in our study. However, only a small fraction of the intracellular metals (including $\mathrm{Zn}$ ) occur in the free ionic form, with the vast majority being incorporated into enzymes or bound by metal chelators such as metallothioneins and glutathione (Andersen and Baatrup, 1988; Finney and O'Halloran, 2003). Nevertheless, the low sensitivity of the crab proteasome towards $\mathrm{Zn}$ may reflect a possible physiological adaption to the naturally high concentrations of $\mathrm{Zn}$ in the crab muscle in vivo. Given the high biochemical similarity between $\mathrm{Zn}^{2+}$ and $\mathrm{Cd}^{2+}$ and similar affinity of these ions to intracellular targets (Zalups and Koropatnick, 2010), adaptation to high intracellular levels of $\mathrm{Zn}$ may also explain the considerably higher tolerance of the crab proteasome to $\mathrm{Cd}$ compared to that of the lobster. The mechanisms of the effects of $\mathrm{Zn}$ or $\mathrm{Cd}$ on proteasome activity are not yet fully understood and may involve direct binding to the proteasome as well as indirect interactions caused by metal-induced oxidative stress, release of essential metals from catalytic sites or intracellular storage, and/or disruption of associated pathways (Funk et al., 1987; Figueiredo-Pereira and Cohen, 1999; Pena et al., 2006). Our in-vitro study indicates that both, Cd and Zn, may affect the chymotrypsin-like proteasome activity directly, at least in lobsters. Differences in susceptibility of the proteasome to $\mathrm{Zn}$ and $\mathrm{Cd}$ between crabs and lobsters indicate potential structural differences at or around the binding sites for these metals on the proteasome of the two species, and require further investigation.

Of the four studied metals, mercury was the strongest inhibitor of the proteasome activity in lobsters and crabs. More than $90 \%$ of activity was suppressed at concentrations above $25 \mu \mathrm{M}$, which matches well with the acute sublethal dose of water-borne mercury ( $\mathrm{LC}_{50}: 6 \mu \mathrm{M}$ to $30 \mu \mathrm{M}$ ) for adult crustaceans (Connor, 1972; Eisler, 1981). Mercury has been shown to interfere with the proteasome activities in other organisms, but the precise mechanisms of the binding of $\mathrm{Hg}$ and $\mathrm{Hg}$ induced inhibition of the proteasome are unknown (Yu et al., 2010). Moreover, the effects of $\mathrm{Hg}$ on the proteasome depend on the mode of exposure and differ between inorganic $\mathrm{Hg}^{2+}$ and organic mercury complexes. Hg was shown to highly inhibit the proteasome in plants and mammalian cell lines (Pena et al., 2008; Yu et al., 2010). However, under in-vivo conditions toxic effects of $\mathrm{MeHg}$ may be counterbalanced by a proteasome-mediated protection. Hwang et al. (2002) and Hwang (2011) demonstrated in yeast and human cell lines that enhanced resistance is mediated through enhanced expression of Cdc34 or Rad23 proteins which are important for ubiquitination, and accordingly, proteasomal degradation. Our study indicates that in crustaceans the exposure to inorganic mercury may suppress also in-vivo significantly the intracellular protein degradation. It is worth noting that, with the exception of cadmium, the relative inhibitory strengths of these metals on the crustacean proteasome correspond well to their respective degrees of toxicity measured for the whole organism. Marine crustaceans are highly sensitive to mercury, copper, and cadmium, and only to a lesser extent towards nickel or zinc (Eisler and Hennekey, 1977; Devi, 1987). This separation in sensitivity reflects distinct physiological traits and characteristics of species for regulating internal metal concentrations through uptake, excretion, or induction of detoxification pathways (Eisler, 1981; Amiard et al., 1987; Viarengo and Nott, 1993; Rainbow, 1995, 2007; Ahearn et al., 2004). Furthermore, abiotic or ecological factors, such as temperature, salinity, lifestyle, feeding mode, metal uptake route, or metal speciation influence rates of absorption and internal metal sequestration. Since metals act at different physiological levels, detailed studies on intracellular biochemical mechanisms can contribute to a better understanding of the complex interaction of environmental pollution and toxic effects in marine invertebrates. Our present study shows that suppression of proteasomal activity may represent a significant mechanism of trace metal toxicity in marine crustaceans, affecting rates of protein degradation and turnover which are essential for proper cell functioning and rapid response to stress (Bayne, 2004).

\section{Acknowledgments}

We are grateful to the crew of R/V Uthörn for providing crabs. I.M.S. was partially supported by Charlotte Research Institute and UNC Charlotte's Faculty Research Grant during the work on this manuscript.

\section{References}

Ahearn, G.A., Mandal, P.K., Mandal, A., 2004. Mechanisms of heavy metal sequestration and detoxification in crustaceans: a review. J. Comp. Physiol. B. 174 (6), 439-452.

Amiard, J.C., Amiard-Triquet, C., Berthet, B., Metayer, C., 1987. Comparative study of the patterns of bioaccumulation of essential $(\mathrm{Cu}, \mathrm{Zn})$ and non-essential $(\mathrm{Cd}, \mathrm{Pb})$ trace metals in various estuarine and coastal organisms. J. Exp. Mar. Biol. Ecol. 106 (1), 73-89. 
Amici, M., Forti, K., Nobili, C., Lupidi, G., Angeletti, M., Fioretti, E., Eleuteri, A.M., 2002. Effect of neurotoxic metal ions on the proteolytic activities of the 20 S proteasome from bovine brain. J. Biol. Inorg. Chem. 7 (7-8), 750-756.

Andersen, J.T., Baatrup, E., 1988. Ultrastructural localization of mercury accumulations in the gills, hepatopacreas, midgut, and antennal glands of the brown shrimp, Crangon crangon. Aquat. Toxicol. 13 (4), 309-324.

Bánfalvi, G., 2011. Heavy metals, trace elements, and their cellular effects. In: Bánfalvi, G. (Ed.), Cellular Effects of Heavy Metals. Springer, Dordrecht, pp. 3-28. http://dx.doi. org/10.1007/978-94-007-0428-2.

Barrento, S., Marques, A., Teixeira, B., Vaz-Pires, P., Carvalho, M.L., Nunes, M.L., 2008. Essential elements and contaminants in edible tissues of European and American lobsters. Food Chem. 111 (4), 862-867.

Baumeister, W., Walz, J., Zühl, F., Seemüller, E., 1998. The proteasome: paradigm of a selfcompartmentalizing protease. Cell 92 (3), 367-380.

Bayne, B.L., 2004. Phenotypic flexibility and physiological tradeoffs in the feeding and growth of marine bivalve molluscs. Integr. Comp. Biol. 44 (6), 425-432.

Berge, J.A., Brevik, E.M., 1996. Uptake of metals and persistent organochlorines in crabs (Cancer pagurus) and flounder (Platichthys flesus) from contaminated sediments: mesocosm and field experiments. Mar. Pollut. Bull. 33 (1-6), 46-55.

Boudreou, S., Worm, B., 2012. Ecological role of large benthic decapods in marine ecosystems: a review. Mar. Ecol. Prog. Ser. 469, 195-213.

Bradford, M.M., 1976. A rapid and sensitive method for the quantification of microgram quantities of protein utilizing the principle of protein-dye binding. Anal. Biochem. 72 (1-2), 248-256.

Ciechanover, A., 2005. Intracellular protein degradation: From a vague idea, through the lysosome and the ubiquitin-proteasome system, and onto human diseases and drug targeting (Nobel Lecture). Angew. Chem. Int. Ed. 44, 5944-5967.

Ciechanover, A., Brundin, P., 2003. The ubiquitin proteasome system in neurodegenerative diseases: Sometimes the chicken sometimes the egg. Neuron 40 (2), 427-446.

Connor, P.M., 1972. Acute toxicity of heavy metals to some marine larvae. Mar. Pollut. Bull. 3 (12), 190-192.

Costello, M.J., Coll, M., Danovaro, R., Halpin, P., Ojaveer, H., Miloslovich, P., 2010. A census of marine biodiversity knowledge, resources, and future challenges. PLoS ONE 5 (8), e12110.

Cvek, B., Milacic, V., Taraba, J., Dou, Q.P., 2008. Ni(II), Cu(II), and Zn(II) diethyldithiocarbamate complexes show various activities against the proteasome in breast cancer cells. J. Med. Chem. 51 (20), 6256-6258.

Daniel, K.J., Gupta, P., Harbach, H.R., Guida, W.C., Dou, Q.P., 2004. Organic copper complexes as a new class of proteasome inhibitors and apoptosis inducers in human cancer cells. Biochem. Pharmacol. 67 (6), 1139-1151.

Devi, V.U., 1987. Heavy metal toxicity to Fiddler crabs, Uca annulipes Latreille and Uca triangularis (Milne Edwards): tolerance to copper, mercury, cadmium, and zinc Bull. Environ. Contam. Toxicol. 39 (6), 1020-1027.

Eichhorn, G.L., 1976. Active sites of biological macromolecules and their interaction with heavy metals. In: McIntyre, A.D., Mills, C.F. (Eds.), Ecological Toxicology Research. Plenum Press, NY, pp. 123-142.

Eisler, R., 1981. Trace metal concentrations in marine organisms. Galveston Bay Bibliography, TX (687 pp.).

Eisler, R., Hennekey, R.J., 1977. Acute toxicities of $\mathrm{Cd}^{2+}, \mathrm{Cr}^{+6}, \mathrm{Hg}^{2+}, \mathrm{Ni}^{2+}$ and $\mathrm{Zn}^{2+}$ to estuarine macrofauna. Arch. Environ. Contam. Toxicol. 6 (1), 315-323.

Engel, D.W., 1987. Metal regulation and molting in the blue crab, Callinectes sapidus: copper, zinc, and metallothionein. Biol. Bull. 172 (1), 69-82.

Engel, D.W., Brouwer, M., Mercaldo-Allen, R., 2001. Effects of molting and environmental factors on trace metal body-burdens and hemocyanin concentrations in the American lobster, Homarus americanus. Mar. Environ. Res. 52 (3), 257-269.

FAO, 2012. The state of world fisheries and aquaculture (Rome, 209 pp.)

Figueiredo-Pereira, M.E., Cohen, G., 1999. The ubiquitin/proteasome pathway: friend or foe in zinc-, cadmium-, and $\mathrm{H}_{2} \mathrm{O}_{2}$-induced neuronal oxidative stress. Mol. Biol. Rep. $26(1-2), 65-69$

Finney, L.A., O'Halloran, T.V.O., 2003. Transition metal speciation in the cell: insights from the chemistry of metal ion receptors. Science 300 (5621), 931-936.

Funk, A.E., Day, F.A., Brady, F.O., 1987. Displacement of zinc and copper from copperinduced metallothionein by cadmium and by mercury: in vivo and ex vivo studies. Comp. Biochem. Physiol. C 86 (1), 1-6.

Gao, Y., de Brauwere, A., Elskens, M., Croes, K., Baeyens, W., Leermakers, M., 2013. Evolution of trace metal and organic pollutant concentrations in the Scheldt River Basin and the Belgian Coastal Zone over the last three decades. J. Mar. Syst. 128, 52-61.

Götze, S., Saborowski, R., 2011. Proteasomal activities in the claw muscle tissue of European lobster, Homarus gammarus, during larval development. J. Comp. Physiol. B. $181,861-871$

Götze, S., Bose, A., Abele, D., Sokolova, I.M., Saborowski, R., 2013. Pitfalls in invertebrate proteasome assays. J. Exp. Biol. 216 (8), 1351-1354.

Grune, T., 2000. Oxidative stress, aging and the proteasomal system. Biogerontology 1 (1) $31-40$.

Heinemeyer, W., Fischer, M., Krimmer, T., Stachon, U., Wolf, W.H., 1997. The active sites of the eukaryotic $20 \mathrm{~S}$ proteasome and their involvement in subunit precursor processing. J. Biol. Chem. 272 (40), 25200-25209.

Hwang, G.-W., 2011. The role of the ubiquitin-proteasome system in methylmercury toxicity in Saccharomyces cerevisiae. J. Health Sci. 57 (2), 129-133.

Hwang, G.-W., Furuchi, T., Naganuma, A., 2002. A ubiquitin-proteasome system is responsible for the protection of yeast and human cells against methylmercury. FASEB J. 16 (7), 709-711.
Järup, L., 2003. Hazards of heavy metal contamination. Br. Med. Bull. 68, 167-182.

Jover, J., Bosque, R., Sales, J., 2008. A comparison of the binding affinity of the common amino acids with different metal cations. Dalton Trans. 45, 6441-6453.

Jung, K., Zauke, G.-P., 2008. Bioaccumulation of trace metals in the brown shrimp Crangon crangon (Linnaeus, 1758) from the German Wadden Sea. Aquat. Toxicol. 88 (4), 243-249.

Kanthasamy, A.G., Choi, C., Jin, H., Harischandra, D.S., Anantharam, V., Kanthasamy, A., 2012. Effect of divalent metals on the neuronal proteasomal system, prion protein ubiquitination and aggregation. Toxicol. Lett. 214 (3), 288-295.

Kim, I., Kim, C.H., Kim, J.H., Lee, J., Choi, J.J., Chen, Z.A., Lee, M.G., Chung, K.C., Hsu, C.Y., Ahn, Y.S., 2004. Pyrrolidine dithiocarbamate and zinc inhibit proteasome dependent proteolysis. Exp. Cell Res. 298 (1), 229-238.

Lehninger, A.L., 1950. Role of metal ions in enzyme systems. Physiol. Rev. 30 (3), 393-429.

Mance, G., 1987. Pollution threat of heavy metals in aquatic environments. Elsevier Applied Science Publisher LTD, London and New York. http://dx.doi.org/10.1007/97894-009-3421-4.

Meng, L., Mohan, R., Kwok, B.H.B., Elofsson, M., Sin, N., Crews, C.M., 1999. Epoxomicin, a potent and selective proteasome inhibitor, exhibits in vivo anti-inflammatory activity. Proc. Natl. Acad. Sci. U. S. A. 96, 10403-10408.

Milacic, V., Chen, D., Giovagnini, L., Diez, A., Fregona, D., Dou, Q.P., 2008. Pyrrolidine dithiocarbamate-zinc(II) and -copper(II) complexes induce apoptosis in tumor cells by inhibiting the proteasomal activity. Toxicol. Appl. Pharmacol. 231, 24-33.

Mirza, R., Mohammadi, M., Sohrab, A.D., Safahieh, A., Savari, A., Hajeb, P., 2012. Polycyclic aromatic hydrocarbons in seawater, sediment, and Rock oyster Saccostrea cucullata from the northern part of the Persian Gulf (Bushehr Province). Water Air Soil Pollut. 223 (1), 189-198.

Mykles, D.L., 1998. Intracellular proteinases of invertebrates: Calcium-dependent and proteasome/ubiquitin-dependent systems. Int. Rev. Cytol. 184, 157-289.

Mykles, D.L., 1999a. Proteolytic processes underlying molt-induced claw muscle atrophy in decapod crustaceans. Am. Zool. 39, 541-551.

Mykles, D.L., 1999b. Structure and functions of arthropod proteasomes. Mol. Biol. Rep. 26, 103-111.

Najle, R., Elissondo, M., Gentile, S., Vacarezza, G., Solana, H., 2000. Histopathology of the digestive gland of an Antarctic limpet exposed to cadmium. Sci. Total Environ. 247 (2-3), 263-268.

Nieboer, E., Richardson, D.H.S., 1980. The replacement of the nondescript term 'heavy metals' by a biologically and chemically significant classification of metal ions. Environ. Pollut. Ser. B Chem. Phys. 1 (1), 3-26.

Pena, L.B., Pasquini, L.A., Tomaro, M.L., Gallego, S.M., 2006. Proteolytic system in sunflower (Helianthus annuus L.) leaves under cadmium stress. Plant Sci. 171 (4), 531-537.

Pena, L.B., Zawoznik, M.S., Tomaro, M.L., Gallego, S.M., 2008. Heavy metals effect on proteolytic system in sunflower leaves. Chemosphere 72 (5), 741-746.

Powell, S.P., Wang, P., Divald, A., Teichberg, S., Haridas, V., McCloskey, T.W., Davies, K.J.A Katzeff, H., 2005. Aggregates of oxidized proteins (lipofuscin) induce apoptosis through proteasome inhibition and dysregulation of proapoptotic proteins. Free Radic. Biol. Med. 38 (8), 1093-1101.

Rainbow, P.S., 1995. Physiology, physicochemistry and metal uptake - a crustacean perspective. Mar. Pollut. Bull. 31 (1-3), 55-59.

Rainbow, P.S., 2007. Trace metal bioaccumulation: models, metabolic availability and toxicity. Environ. Int. 33 (4), 576-582.

Rainbow, P.S., White, S.L., 1989. Comparative strategies of heavy metal accumulation by crustaceans: zinc, copper and cadmium in a decapod, an amphipod and a barnacle. Hydrobiologica 174 (3), 245-262.

Ramakritinan, C.M., Chandurvelan, R., Kumaraguru, A.K., 2012. Acute toxicity of metals: $\mathrm{Cu}, \mathrm{Pb}, \mathrm{Cd}, \mathrm{Hg}$ and $\mathrm{Zn}$ on marine molluscs, Cerithedia cingulata G., and Modiolus philippinarum H. Ind. J. Geo-Mar. Sci. 41 (2), 141-145.

Rock, K.L., Gramm, C., Rothstein, L., Clark, K., Stein, R., Dick, L., Hwang, D., Goldberg, A.L., 1994. Inhibitors of the proteasome block the degradation of most cell proteins and the generation of peptides presented on MHC class I molecules. Cell 78 (5), 761-771.

Soto-Jiméneza, M.F., Páez-Osuna, F., 2001. Distribution and normalization of heavy metal concentrations in mangrove and lagoonal sediments from Mazatlán harbor (SE Gulf of California). Estuar. Coast. Shelf Sci. 53 (3), 259-274.

Stoeppler, M., Nürnberg, H.W., 1979. Comparative studies on trace metal levels in marine biota III. Typical levels and accumulation of toxic trace metals in muscle tissue and organs of marine organisms from different European seas. Ecotoxicol. Environ. Saf. 3 (4), 335-351.

Storelli, M.M., Marcotrigiano, G.O., 2003. Heavy metal residues in tissues of marine turtles. Mar. Pollut. Bull. 46 (4), 397-400.

Vallee, B.L., Ulmer, D.D., 1972. Biochemical effects of mercury, cadmium and lead. Annu. Rev. Biochem. 41, 91-128.

Viarengo, A., Nott, J.A., 1993. Mechanisms of heavy metal cation homeostasis in marine invertebrates. Comp. Biochem. Physiol. C 104 (3), 355-372

Voges, D., Zwickl, P., Baumeister, W., 1999. The 26S Proteasome: a molecular machine designed for controlled proteolysis. Annu. Rev. Plant Physiol. Plant Mol. Biol. 68, 1015-1068.

Yu, X., Robinson, J.F., Sidhu, J.S., Hong, S., Faustmann, E.M., 2010. System-based comparison of gene expression reveals alterations in oxidative stress, disruption of ubiquitinproteasome system and altered cell cycle regulation after exposure to cadmium and methylmercury in mouse embryonic fibroblast. Toxicol. Sci. 114 (2), 356-377.

Yuan, H., Song, J., Li, N., Duan, L., 2012. Distribution and contamination of heavy metals in surface sediments of the South Yellow Sea. Mar. Pollut. Bull. 64 (10), 2151-2159.

Zalups, R.K., Koropatnick, J., 2010. Cellular and molecular biology of metals. CRC Press, Taylor and Francis Group, Boca Raton, London, New York (414 pp.). 